\title{
Re-Adaptation of Traditional Malay House Concept as A Design Approach for Vertical Dwellings Malays
}

\author{
Nordin Misnat ${ }^{1}$, Mastor Surat ${ }^{2}$, Ismar M.S. Usman ${ }^{2}$ and \\ Norfazillah Binti Ahmad ${ }^{3}$ \\ ${ }^{1}$ Postgraduate Studies, Architecture Department, Faculty of Built Environment and Engineering , Universiti Kebangsaan Malaysia, \\ UKM Bangi, Malaysia \\ ${ }^{2}$ Architecture Department, Faculty of Built Environment and Engineering, Universiti Kebangsaan Malaysia, UKM Bangi, Malaysia \\ ${ }^{3}$ Interior Architecture Department, Faculty of Architecture, Planning and Surveying, Universiti Teknologi MARA, UiTM Cawangan \\ Perak, Seri Iskandar, Perak \\ *Corresponding author E-mail:lightdin@gmail.com
}

\begin{abstract}
Home is a basic need of human life and plays an important role in wellbeing human life. The quality of design should meet the needs and way of life as every human being deserves to enjoy it. Today's housing design failed to respond in meeting the needs of the occupants. The designs are now too much influenced from the west and contrary to the needs of the local design, especially the Malays. The space for the Malay Muslims is the reflection of the fulfilment of its way of life. The occupants are experiencing multiple unfavourable housing issues. This paper highlight the housing issues and conditions on how certain issues of housing affordability affect societal wellbeing. The writing of this study will discuss the issues and problems of residential low and medium cost-of-modern design houses. Forty-five willing respondents were randomly selected to answer questionnaires based on their willingness and the data were analysed using SPSS statistics to interpret these issues. The findings will be the basis for addressing the main issues and to proposed the application of the conceptual Malay heritage design in the design towards the creation of quality interior design dwelling.
\end{abstract}

Keywords: Traditional Malay House; Affordable House; Spatial Planning Design; Sustainability; Wellbeing,

\section{Introduction}

As a basic necessity in human life, a home should fulfil its will and function against the physical and physiological dimensions until it is described as the home of heaven. A good and quality home design is a reflection of the needs of the occupants. Interior space design should fulfil its function on the needs of the day-today activities of the residents and thus have a good impact on the achievement of a prosperous, safe and healthy life. Homes are designed to meet various goals and activities. The design of residential and interior space should have the elements to translate and reflect it. Modern housing designs, especially in Malaysia, have been heavily influenced by inappropriate western designs for local culture and activities [1]. As a result, the design has affected the occupants. Home design is a manifestation of its inhabitants. In contrast to the rest of the race, Malays live a life based on a culture that defines Islam as the principle of life. The current issue of the ability to own a home has become a pressure for the lower and middle-income groups on the issue of rising house prices from time to time. The findings from [2], states that housing prices continue to rise and less choices are available for middle-income groups as they found it difficult to own a house at the location they like. Apart from the comfort issues after having the housing also need to be paid attention, especially from the comfort of the environment and the interior space to meet the demands of the residents have not yet reached. For these people, owning their own home is a basic necessity and signalling that they have managed to get out of poverty [3]. But life, in occupying a home after succeeding it is a determinant of the comfort and well-being of their lives. Modernized multi-storey homes have problems in meeting the needs of the residents. It is quite a burden for them to improve the features that are not in line with their home function especially after large amount is used for the purpose of purchasing the home. With the limited choice of ownership decisions according to their ability. According to Tajuddin Rasdi [4], states that the current home design fails to meet the culture and the life of its occupants. The design is too much influenced by the west and does not conform to the needs of the residents, not based on the culture and surrounding environment. The impact of these environmental constraints and modernity has led to social problems, unhealthy environment and pressure on the occupants [5]. Many studies have been conducted to examine housing issues regarding comfort and satisfaction that show the design of existing houses has failed to respond to residents' needs. Accordingly, the purpose of this paper is to identify the real issues and problems that are being encountered by the residents of Kinta Valley, Ipoh, Perak.

\section{Literature Review}

Referring to Dictionary of Architecture and Building Construction is defined as a stand-alone dwelling with a living space for one family unit [6]. Housing as a basic concept, aimed at addressing 
the basic needs of shelter and human security by providing protection against climatic conditions and undesirable invasion which may endanger our well-being. Sufficient shelter means adequate privacy; adequate space; physical access; adequate security; time security; structural stability and durability; lighting, heating and ventilation; adequate basic infrastructure, such as water supply, sanitation facilities and waste management; appropriate environmental quality and health-related factors; and adequate and accessible locations related to basic work and amenities, all should be provided at reasonable cost [7].

Whereas for the Malays, the home is a social symbol of life in Malay culture. A home is not just a place to live where life is done as well, but it is also a symbol of perfection of life. According to Ezrin Arbi [8], the home is a manifestation of life for the Malays. It is a reflection of life. Construction of houses should take into account the various aspects and accuracy by highlighting the features that reflect the cultural values of the people [9]. Following that way the perfection of the interior and the interior of the inhabitants can be fulfilled. The value of Malay culture is based on the main aspects of Islam, customs and Malay traditions [10]. Malay customs and traditions enforce Islam. He explained that the house was a place of birth, was expanded and taught where the home was the place of all scholars, life and family and ancestry. The Malay house architecture was built to fulfil the deed of action in line with the cultural and functionary provisions of the Malay community [1]. In order to provide these needs the planning and construction of houses should be based on their features and cultural guidelines. The characteristics of the Malay house are not merely of the carvings but it also covers the aspects of neighbourhood, spirit of the community, ties with nature, relationships with the Creator, construction techniques and builders, planning and host economic factors. The combination of all these aspects makes the Malay house a refined home architecture of reflection to its culture [10]. In summary, housing is the fundamental right of every human being that satisfies the reasonable needs of every individual, family institution and society.

\subsection{Affordable Housing}

The $11^{\text {th }}$ Malaysia Plan (2016-2020) by the government outlines the provision of quality affordable housing for all of life, especially for medium and low income households. This vision is an important foundation in creating a strong and stable society, with better economic, education and health outcomes for individuals, families and communities [11]. The term 'affordable housing' refers to housing finance capability in respect of resident income [12]. The incredible urban growth around the world has urged building a residence for a large number of people in cities and towns around the world [13]. However, the construction of this residence should meet the quality that should be ensured. The $10^{\text {th }}$ Malaysia Plan (2010-2015) has outlined some of the challenges among which is a clear mismatch between supply and demand for housing; meet the demand for sustainable environmental design and improve the quality of new and existing housing.

Based on past experience, private housing developers are seen only targeting revenue versus the resulting quality. Most homes are very basic with less satisfactory quality in the housing, family, comfort, social, cultural and religious needs [14]. Therefore, the balance between providing adequate minimum room quality for resident satisfaction at the same time has an economic value for private developers [15]. The term housing quality not only meets the basic human needs but also contributes to the physical and psychological well-being of the occupants life. The term housing quality also covers the quality of construction, hygiene, neighbourhood, facilities, security, and interior space. Discussions on the aspects of internal space are have scarcely been given any serious academic attention compared to other aspects. Therefore, this paper focuses on internal space planning that explores some of the key issues and suggests strategies to address the problems faced.

\subsection{Aspiration from the Past}

The traditional Malay house is one of Malaysia's richest cultural heritage components. Houses designed and constructed by their own users - Malays in Malaysia - according to their own needs and with a good understanding of nature and the environment, combining and reflecting on their way of life and culture [16], [10] According to M. Sabriza'a et. al. [17] and Zulkifli Hanafi [18], the design and process of the construction of traditional Malay houses are important aspects in the practice of Malay traditional houses especially from the selection of materials and building materials, energy efficiency, sustainable site planning, environmental qualities, indoor environmental quality it was a perfect and sustainable design in the past to be the design of today's and future designs. Eco-friendly and climatic design - The traditional Malay house has a design that can be adapted to weather and environments characterized by high temperature and humidity. The average temperature in Malaysia is $22^{\circ} \mathrm{C}$ up to $33^{\circ} \mathrm{C}$ throughout the year [16]. Therefore, the traditional Malay house design has features such as firstly allow adequate ventilation for cooling and reduction of humidity by having full-height operable windows, upper ventilation grilles and minimal internal partitions for adequate cross ventilation and raised-on-stilts lightweight construction with open under floor space using low thermal conductivity materials such as timber and thatch. Secondly, use building materials with low thermal capacity so that little heat is transmitted into the house. Thirdly, control direct solar radiation, control glare from the open skies and surroundings by having large roof eaves and low walls to control direct solar radiation and protect against rain. Ensure adequate natural vegetation in the surroundings to provide for a cooler micro-climate [16]. The whole situation makes it an energy-saving and sustainable design [18].

Interior space planning - is the most important feature in the design of traditional Malay houses because space planning is in accordance with a hierarchy that connects the function and living of the occupants [19]. If viewed from the level of the traditional Malay house designs divided into three roofing elements, the interior space elements and the feet [10]. Whereas, from horizontal perspective, interior space planning is divided into public spaces such as Serambi, Anjung space for the reception of outside and neighbourhood guests. Functions for certain occasions such as ceremony, festival and crowd. Semi-public space such as the core house is the main hall and multi-function area for worship activities, gatherings, and daily family activities. A semi-private room like 'Selang'or intermediate is a connecting space between a mother's house and a kitchen used for social and income-generating women. While private rooms such as rooms and kitchens are used for daily activities of family members such as food preparation and clothing salons [18]. The essence of the interior space planning is :

a) Multi-function - space has various functions to carry out daily activities as an example of Serambi space function as a lounge at the same time can be used as guest lounge [10].

b) Flexible - space functions can be adapted to the changing and current needs of the occupants. For example, the Malay house can grow and shrink either from the angle of the building structure or the use of its space [20]. This organic design depends on the factors of economic ability, the development of family members and the current activity of the owner of the house. Flexible space concepts need to be explored more deeply and adapted to the modern housing de- 
sign as an approach in addressing issues and problems encountered.

c) Open space - minimal use of minimalist furniture and walls makes the space look spacious and the louvres panel design keeps the room fresh and less hot [16].

d) Privacy - space layout creates a clear boundary between family members and guests in meeting religious demands [10].

e) Spatial arrangement - The inter-relationship between the elements of space design is closely related to the activity and function of space based on Malay culture and traditions that form the rules that determine the hierarchy of spatial importance in traditional Malay house [10].

f) House orientate on the east-west has the advantages of solar reducing effect and match with Islamic requirement for the orientation of Qibla Mecca [18].

Building technology - the traditional Malay house is built modularly according to the needs, functions and abilities of the homeowner economics, such as the core house, the kitchen and the other spaces [10]. The traditional Malay house is a timber house raised on stilts. It is basically a post-and-lintel structure with wooden or bamboo walls and a thatched roof [21]. More interestingly, the process of building a house is to involve the homeowner from the design stage, site selection and construction orientation, selection of materials until the house is ready to be built.

The concept of measurement in the construction of the Malay House refers to the size of the owner's human body. Measurements refer to male limbs (Husband) for the height of the home and women (wives) for the size of the home [9]. Rationally based on the size of the limbs make it meet the size of the human anthropometric and ergonomics. The suitability of this measure is well translated into Malay housing space planning. For example, the size of the Serambi size is appropriate to its function as a space for performing prayer and relaxation activities such as sleeping at night times.

In conclusion, the design of this intelligent and unique traditional Malay space house is a priority for the comforts of its inhabitants, including its surroundings, functions, social, cultural and religious backgrounds. All of these elements should be adapted back to modern buildings, especially vertical dwelling as a strategy to address the problems faced primarily on the issue of writing this paper.

\section{Methodology}

Methods of interviewing and feedbacks respond from occupants based on their experience in the residence of the multi-storey residential unit they occupied the Kinta Valley area, Ipoh, Perak. Respondents were randomly selected for comfort levels related to several issues and problems related to multilevel housing among Malay residents. Forty-five people selected according to the willingness to answer questions about the level of comfort, health, safety and satisfaction encompass the social, cultural, and economic aspects of living in their homes. Observation studies on residential units are carried out and space layout data are recorded with sketches and photographs to understand the problem. Scientific studies of secondary data through thesis, journal, articles, books and others to meet the objectives of the study. The focus of the study is on the quality of housing, neighbourhood, resident attitude, residential design in understanding, addressing and solving the problem effectively. Writing in this study will focus on internal space planning issues and strategies to address them.

\section{Result and Discussion}

From the interview survey and observation the dwelling unit on the focusing writing issue respondents' feedback, firstly that they were uncomfortable with the condition of the interior. Especially entry space into homes in front of neighbouring lots poses discomfort to visual privacy. An unsuitable layout such as the position of the kitchen space is placed adjacent to the entrance, the position of the rooms located near the living room creates a discomfort to keep the view and privacy especially when receiving guests. These results show that uncomfortable space issues are still a major issue in the multi-storey living space as shown in the Figure 1 typical layout of dwelling unit at Lembah Kinta, Ipoh, Perak.

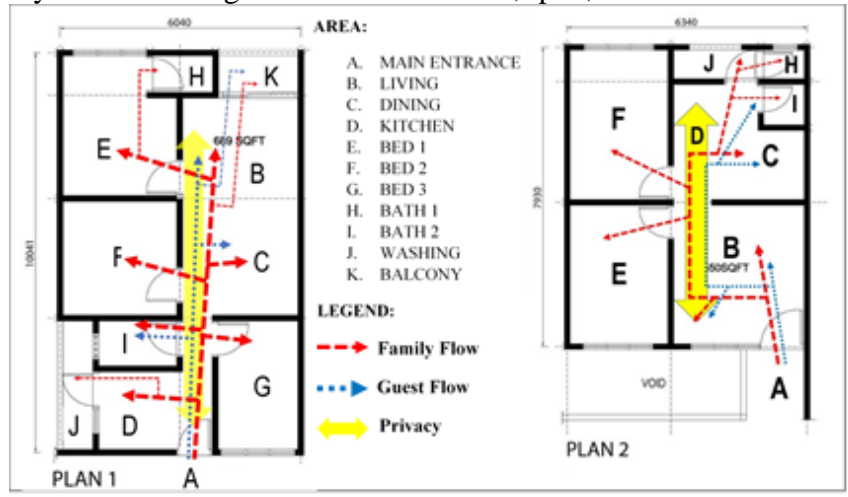

Figure 1: Typical Layout Plan of 3 and 2 bedroom dwelling unit and internal occupants movement flow.

Secondly, other respondents argue that the size of their living space is tight and narrow for daily activity purposes. The condition is due to the inadequate room space and the size of the space especially when there is an event or ceremony. For example, wedding ceremonies, prayer, feast days and other occasions are only able to accommodate a small amount of attendance as compared to the number of guests planned.

Thirdly, respondents also informed that there was a problem of space for guests such as family members and relatives who wanted to stay overnight in accordance with the size and number of existing rooms. The situation is unfortunate when guests are forced to use the living room as a bed due to privacy issues and safeguarding aurat. They also argued that the main spaces such as living room, kitchen and room were very small and unable to accommodate the activities carried out. While there is not enough space for storage of goods, especially useful items in season.

Finally, the majority of respondents think that their home needs to be upgraded to meet their comfort needs. Respondents also argued that high-cost factors and adequate income should be taken into account for this purpose. Although there are some constraints for them to make modifications, especially involving building structures, building by law and conditions of building management that does not give permission to change some of the original positions of the building. This condition makes the pressure and constraints of the occupants in fulfilling their satisfaction.

\section{Conclusion}

The findings clearly show that there is required attention in reducing housing issues among them ; first of all respondents feel uncomfortable with their interior space conditions; both sizes are some narrow interior space and cannot accommodate daily activities; Furthermore, their interior space is needed to be upgraded to meet their needs; finally respondents plan to stay in the residence because there is no option to move elsewhere.

Several steps need to be taken by the relevant parties, including implementing appropriate design approaches into the construction planning for new housing to meet the needs of the occupants; the 
provision of space size according to the healthier side of the human scale to accommodate the daily activities of the occupants; flexible space design, user-friendly, more economical and sustainable design for future needs. The flexibility need to be explored more deeply and adapted to the design of modern housing as a strategy in addressing issues and problems encountered. Further studies to be conducted on the suitability of the conceptual design concept of the traditional Malay house space as it has been proven to address many problems, more economically and environmentally friendly. Finally, it is hoped that this study will contribute the use of research data to certain parties whether at the design planning stage or to the implementation of housing for the construction of new residential projects in reducing housing-related issues. The design approach based on sustainable, green environment, humanity and spiritual factors is the manifestation and reflection of the lives of the Malays towards the well-being of the dreamed life.

\section{Acknowledgement}

I would like to acknowledge and extend heartfelt gratitude to The Ministry of Education and Universiti Teknologi MARA (UiTM) for funding my study. My sincere thanks to Ar. Dr. Mastor Surat for his support and all my colleagues who kindly provided valuable and helpful comments of this paper.

\section{References}

[1] Mastor Surat (2012), Mengenalpasti Tahap Kesejahteraan Seni Bina Warisan Melayu Melalui Konsep Islam. Jurnal Design and Built, Vol. 5, 2012

[2] Shadiya M. S. Baqutayan (2014), The Affordable Housing Stress among Middle-Income Group. IOSR Journal Of Humanities And Social Science (IOSR-JHSS), 19(7), 82-90.

[3] Mohd Razali Agus (2001), Perumahan Awam Di Malaysia, Dasar dan Amalan.Utusan Publications \& Distributors Sdn. Bhd

[4] M. Tajuddin M. Rasdi (2009), The Architectural Heritage Of The Malay World. Skudai: Penerbit Universiti Teknologi Malaysia.

[5] Zakiyah Jamaludin (2001), Kepuasan Terhadap Perumahan dan Sistem Perumahan Berkonsepkan Islam. Sekolah Pembangunan Sosial, Universiti Utara Malaysia, Vol. 2.

[6] Nikolai Davies et. al. (2008), Dictionary of Architecture and Building Construction. Elsevier Ltd.USA.

[7] World Health Organization (WHO) Regional Office for Europe The LARES project (Large Analysis and Review of European housing and health Status), Retrieved April 2016 from http://www.euro.who.int/Housing/activities/20020711_1

[8] Ezrin Arbi (1997), Ke Arah Jatidiri Senibina Dalam Konteks Nusantara, kertas kerja Simposium Nusantara , UiTM Cawangan Perak, Kampus Seri Iskandar, 21 Jun 1997.

[9] Jamaluddin Md. Jahi, Noor Faizah Aziz, Kadir Arifin \& Aziz Ujang (2014), Pengaruh Adat Resam, Kepercayaan dan Kebudayaan terhadap Pembinaan Rumah Melayu Tradisional. International Journal of the Malay World and Civilization.

[10] A. Halim Nasir \& W. Hashim W. Teh (1994), Rumah Melayu Tradisi. Penerbit Fajar Bakti Sdn. Bhd.

[11] Economic Planning Unit. (2015), Eleventh Malaysia Plan 2016 2020. Putrajaya: The Economic Planning Unit, Prime Minister's Department.

[12] Habitat, U. N. (2011), Cities and climate change: Global report on human settlements 2011. London, Royaume-Uni, Etats-Unis: UNHabitat.

[13] Zehadul Karim, A. H. M. (2013), Living condition in the low cost apartments in Malaysia: An empirical investigation. Asian Social Science, 9(17), 20-29. http://doi.org/10.5539/ass.v9n17p20

[14] Sulong, M. (1984), Perumahan Awam Kos Rendah di Terengganu: Isu, Masalah dan Penerimaan Masyarakat. Malaysia: Universit Kebangsaan Malaysia.

[15] N. Haniza Ishak, Ati. R. M. Ariffin, Raha Sulaiman, M. Najib N. Zailani (2016), Rethinking Space Design Standards Toward Quality Affordable Housing in Malaysia. MATEC Web of Conferences 66, 00112, IBCC2016. DOI:10.1051/matecconf/20166600112.
[16] Lim J. Yuan (1987), The Malay House. Rediscovering Malaysia's Indigenius Shelter System. Institut Masyarakat.

[17] Sufian C. Amat \& Mohd. Sabriza'a A.Rashid. (2009), An Analysis of the Traditional Malay Architecture as Indicators for Sustainability: A n Introduction to its Genius Loci. Proceedings of Arte-Polis $3^{\text {rd }}$ International Conference on Creative Collaboration and the Making of Place. Bandung, Indonesia.

[18] Zulkifli Hanafi (2012), Towards a Sustainable Built Environment in Malaysia. Sustainable Design: Learning from the Traditional Malay Architecture. Universiti Science Malaysia, pp.155-177.

[19] Shireen Jahn, Norwina M. Nawawi \& Noor H. A. Majid, (2017). The Resilience of Tradition: Malay Allusions in Contemporary Architecture. (S. J. Kashim, Ed.). Penang: Areca Books.

[20] Nangkula Utaberta \& Kamarul A. Kosman, (2009), Rumah yang Berkembang: Pengajaran daripada Keanjalan Matematik pada Rumah Tradisional Melayu. Seminar Bulanan Etnomatematik Rumpun Melayu.

[21] Phillip Gibbs, (1987), Building a Malay House. Singapore: Oxford University Press. 